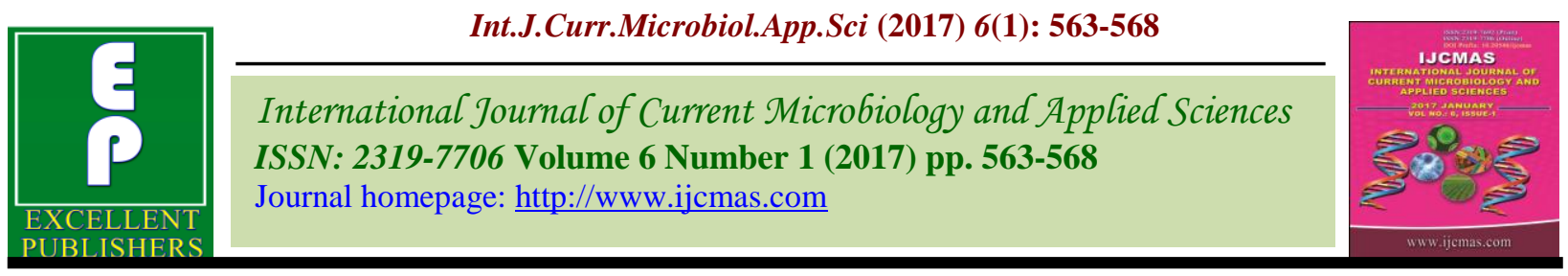

Original Research Article

http://dx.doi.org/10.20546/ijcmas.2017.601.069

\title{
A Leptospirosis Workup by Evaluation of Efficiency of Two Rapid Immunodiagnostic Tests in Comparison with Microscopic Agglutination Test
}

\author{
H.R. Ganesh, Vimal Kumar Karnaker" and Veena A. Shetty \\ Department of Microbiology, K.S.Hegde Medical Academy, Deralakatte, Nithyanandanagar \\ Post, Mangalore-575018, India \\ *Corresponding author
}

A B S T R A C T

\begin{tabular}{|l|}
\hline Ke y w o r d s \\
$\begin{array}{l}\text { Immunochromatogr } \\
\text { aphy test, ELISA, } \\
\text { Leptospirosis, } \\
\text { Microscopic } \\
\text { agglutination tests. }\end{array}$ \\
\hline Article Info \\
\hline $\begin{array}{l}\text { Accepted: } \\
\text { 29 December } 2016 \\
\text { Available Online: } \\
\text { 10 January } 2017\end{array}$ \\
\hline \hline
\end{tabular}

Serological tests plays an important role in the diagnosis of leptospirosis as many clinical manifestations simulate diseases like dengue fever, hepatitis, Enteric fever and Malaria. Laborious and time consuming MAT, a gold standard test led to the introduction of Immunochromatography based tests, card tests and various ELISA kits for rapid diagnosis of acute leptospirosis by peripheral laboratories. The objective of our study was to know the efficacy of the tests like Leptocheck WB IgM(ICT), PanBio IgM ELISA(ELISA), with MAT. Hundred and eleven serum samples from 54 patients with clinical suspicion of leptospirosis and 50 serum from asymptomatic subjects was tested for $\operatorname{IgM}$ antibodies by the kits. Out of 54 serum collected, $42.59 \%$ were positive by ICT, $48.14 \%$ by ELISA, and $53.7 \%$ by MAT. ICT on comparison with MAT showed sensitivity of $75 \%$ and $77.4 \%$, Specificity of $96 \%$ and $95.6 \%$, Positive Predictive value (PPV) 95.7\% and 96\%, Negative Predictive Value (NPV) $77.4 \%$ and $75.9 \%$ respectively and Kappa value 0.707 .ELISA recorded a sensitivity of $89.7 \%$ and $90.3 \%$, specificity of $100 \%$, PPV of $100 \%$, NPV $89.3 \%$ and 88.46 respectively and Kappa value 0.889 with MAT. As ELISA was more sensitive and specific in picking up leptospiral cases early in the infection when compared to ICTs, thusshould be included with ICTs in laboratories to increase the detection of suspected cases of acute leptospirosis with history of 4-6 days of febrile illness.

\section{Introduction}

Laboratory diagnosis of Leptospirosis is a vital part in the diagnosis of this disease as many clinical manifestations simulate other diseases like dengue haemorrhagic fever, serum Hepatitis, Enteric fever, Malaria and many others. Serological tests play a main role in differentiating these diseases (Faine, 1982; Levett, 2001).

Microscopic Agglutination Test is the standard test employed in centres for confirming the cause of the disease (Levett, 2001; WHO, 2003). This test requires a panel of locally prevalent live leptospires which has to be maintained for routine procedures. The procedure is very laborious, time consuming and may cause cross infections in laboratories (WHO, 2003; Cumberland, 1999), following which many peripheral laboratories employ Immuno-chromatography based tests, card tests, spot tests and various ELISA kits for rapid diagnosis of acute leptospirosis (Adler 
et al., 1980; Terpstra et al., 1980; Winslow et al., (1997); Gussenhoven et al., 1997; Smits et al., (2001).

The objective of the study was to know the efficacy of routinely used tests like LeptocheckWB IgM, PanBio IgM ELISA, with respect to the gold standard MAT.

\section{Materials and Methods}

Hundred and eleven serum samples were obtained from 54 patients who were clinically suspected for leptospirosis(test group).First Serum samples from 50 fifty asymptomatic subjects(controlgroup) were also screened for leptospiral antibodies by these serological tests.rapid tests were conducted at K.S.Hegde Medical Academy and Hospital Mangalore and the MAT test was done at TANUVAS, Zoonosis Research Laboratory Chennai.The serum samples were collected during the period July 2011 to October 2012.The study was done only after obtaining institutional ethical clearance and informed consent from the patients.

\section{Inclusion criteria}

Test group: included patients' with clinical suspicion of leptospirosis following Faines ${ }^{6}$ criteria that included fever, headache, nausea,vomiting, abdominal pain, calf pain, conjunctival suffusion, pedal edema and renal failure (Faine, 1982). Also includes the environmental factors like floods, animal reservoirs and state of occupation.Control group included patients with absence of fever and no complaints of acute leptospirosis.

\section{Exclusion criteria}

Other causes of acute febrile diseases such as enteric fever, dengue and malaria.

A. Collection of serum sample: first sample on admission (Acute sera)(54nos).(2-7 days), Second sample(54 nos.) -(8-14 days)

B. Serological Tests done:

1.Genus specific tests:

a. Leptocheck -WB IgM card test(ICT).

b. PanBio ELISA IgM(ELISA)

2.Serogroup/Serovar specific tests:

Microscopic Agglutination test(MAT)

C. Methodology:

The procedure was followed according to the manufacturer's insert in the kits for Leptocheck-WB IgM and PanBio IgM ELISA (Winslow et al., and Gussenhoven, 1997). MAT procedures were followed from research articles with minor modifications. A group of 13 serogroup/serovars of Leptospira were included for screening the serum.

Serovars used are Australis australis (Ballico), Autumnalis autumnalis (Rachmati), Ballum ballum (S102), Canicola canicola (HondUtrechtIV), Grippotyphosa grippotyphosa (MoskvaV), Hebdomadis hebdomadis, Icterohaemorrhagia icterohaemorrhagiae (Copenhageni), Javanic javanica (Veldrat Bat. 46), Pomona pomona (Pomona), Pyrogenes pyrogenes(Salinem), hardjo Sejroe(Sejroe), Tarassovi tarassovi (Perepelitsin),Semaranga patoc (patoc 1) (World Health Organization, 2003 and Cumberland et al., 1997 and Cole et al., 1973).

D. Statistical analysis :Sensitivity(Sn), Specificity (Sp), Positive Negative value (PPV), Negative Predictive value(NPV), Degree of agreement(kappa value) calculated with respect to MAT using SPSS 16. 


\section{Results and Discussion}

The efficacy of two methods were carried out in this study, of which two were commercial test kits (Leptocheck and PanBIO ELISA), and the gold standard MAT. Out of the 54 serum collected during the admission of clinically suspected cases, (42.59\%) were positive by Leptocheck WB IgM, (48.14\%) by PanBIO ELISA, and $(53.7 \%)$ by MAT. The LeptocheckWB on comparison with MAT showed Sn of $75 \%$, Sp of 96\%, PPV 95.7\%, NPV 77.4\% and Kappa value (Value of Agreement) 0.707. PanBio IgM ELISA recorded a $\mathrm{Sn}$ of $89.7 \%$, Sp 100\%, PPV $100 \%$, NPV $89.3 \%$ and Kappa value was 0.889. with MAT (Table 1).

A report of second sera collected is as follows. Leptocheck WB IgM showed positivity of 25 (46.3\%), 28(51.9\%) by PanBIo ELISA and $57.4 \%$ by MAT. The immunochromatography based test showed a sensitivity of $77.4 \% \quad(24 / 31)$, Specificity 95.7\% (22/23), PPV 96.0\% (24/25), NPV $75.9 \%(22 / 29)$ and Measure of agreementKappa value-0.707 with MAT(Table1).

Table.1 Comparison of Leptocheck WB and ELISA with MAT

(Admission and second sample)

\begin{tabular}{|c|c|c|c|c|c|c|c|}
\hline \multirow{7}{*}{$\begin{array}{c}\text { Acute } \\
\text { sample (1-7 } \\
\text { days) } \\
\text { median-4 } \\
\text { days }\end{array}$} & & \multicolumn{2}{|c|}{ Leptochek WB IgM } & \multicolumn{2}{|c|}{ Panbio ELISA IgM } & \multicolumn{2}{|r|}{ MAT } \\
\hline & & $\begin{array}{l}\text { Clinically } \\
\text { suspected }\end{array}$ & Asymptomatic & $\begin{array}{l}\text { Clinically } \\
\text { suspected }\end{array}$ & Asymptomatic & $\begin{array}{l}\text { Clinically } \\
\text { suspected }\end{array}$ & Asymptomatic \\
\hline & $\begin{array}{l}\text { Total } \\
\text { cases }\end{array}$ & 54 & 50 & 54 & 50 & 54 & 50 \\
\hline & Positive & 23 & 02 & 26 & 03 & 29 & 06 \\
\hline & Negative & 31 & 48 & 28 & 47 & 25 & 44 \\
\hline & Sensitivity & \multicolumn{2}{|r|}{$75 \%$} & \multicolumn{2}{|c|}{$89.7 \%$} & \multicolumn{2}{|c|}{$64.8 \%$} \\
\hline & Specificity & \multicolumn{2}{|r|}{$96 \%$} & \multicolumn{2}{|c|}{$100 \%$} & \multicolumn{2}{|r|}{$88 \%$} \\
\hline & PPV\%* & \multicolumn{2}{|c|}{$95.7 \%$} & \multicolumn{2}{|c|}{$100 \%$} & \multicolumn{2}{|c|}{$82.86 \%$} \\
\hline & NPV\%\# & \multicolumn{2}{|c|}{$77.4 \%$} & \multicolumn{2}{|c|}{$89.3 \%$} & \multicolumn{2}{|c|}{$63.79 \%$} \\
\hline & $\begin{array}{c}\text { Kappa } \\
\text { value with } \\
\text { MAT }\end{array}$ & \multicolumn{2}{|c|}{0.707} & \multicolumn{2}{|c|}{0.889} & & \\
\hline $\begin{array}{l}\text { Second } \\
\text { sample }\end{array}$ & $\begin{array}{l}\text { Total } \\
\text { cases }\end{array}$ & 54 & 00 & 54 & 00 & 54 & 00 \\
\hline Days 8-13 & Positives & 25 & - & 29 & - & 31 & - \\
\hline \multirow{6}{*}{$\begin{array}{c}\text { Median -11 } \\
\text { days }\end{array}$} & Negatives & 29 & - & 25 & - & 23 & - \\
\hline & Sensitivity & $77.4 \%$ & - & $90.3 \%$ & - & - & - \\
\hline & Specificity & $95.7 \%$ & - & $100 \%$ & - & - & - \\
\hline & PPV\%* & $96 \%$ & - & $100 \%$ & - & - & - \\
\hline & NPV\%\# & $75.9 \%$ & - & $88.46 \%$ & - & - & - \\
\hline & $\begin{array}{c}\text { Kappa } \\
\text { value }\end{array}$ & 0.707 & - & 0.888 & - & - & - \\
\hline
\end{tabular}

*PPV-positive predictive value, \#NPV- Negative predictive value 
Table.2 Leptocheck WB/Other ICTs

\begin{tabular}{|l|l|l|l|l|l|l|l|l|}
\hline $\begin{array}{l}\text { Author and } \\
\text { year }\end{array}$ & \multicolumn{4}{|c|}{ Admission sample } & \multicolumn{5}{c|}{ Second sample } \\
\hline & Sn & Sp & PPV & NPV & Sn & Sp & PPV & NPV \\
\hline $\begin{array}{l}\text { Blacksell et } \\
\text { al. 2006 }\end{array}$ & $\begin{array}{l}47.3 \\
\%\end{array}$ & $75.5 \%$ & $21.6 \%$ & $91.1 \%$ & - & - & - & - \\
\hline $\begin{array}{l}\text { Panwala } \\
\text { Tanvi et al } \\
\text { 2011 }\end{array}$ & 98.36 & 86.95 & 86.95 & 98.36 & 87.87 & 88 & 90.82 & 84.61 \\
\hline $\begin{array}{l}\text { Goris MG et } \\
\text { al 2013 }\end{array}$ & 78.0 & 98.0 & - & - & - & - & - & - \\
\hline $\begin{array}{l}\text { Panwala tanvi } \\
\text { et al 2015 }\end{array}$ & 84.8 & 37.3 & 40 & 83.3 & - & - & - & - \\
\hline $\begin{array}{l}\text { Niloofa et al } \\
\text { 2015 }\end{array}$ & 84.6 & 73.3 & 60.9 & 90.6 & 80.8 & 76.9 & 70.3 & 85.6 \\
\hline Our study & $75 \%$ & $96 \%$ & $95.7 \%$ & $77.4 \%$ & $77.4 \%$ & $96 \%$ & $76 \%$ & $75.9 \%$ \\
\hline
\end{tabular}

Sn-Sensitivity :Sp-Specificity,PPV-Positive Predictive value ; NPV- Negative predictive value.

Table.3 PanBio ELISA/Verion Serion

\begin{tabular}{|l|l|l|l|l|l|l|l|l|}
\hline $\begin{array}{l}\text { Author and } \\
\text { year }\end{array}$ & \multicolumn{4}{|c|}{ Admission sample } & \multicolumn{5}{c|}{ Second sample } \\
\hline & Sn & Sp & PPV & NPV & Sn & Sp & PPV & NPV \\
\hline $\begin{array}{l}\text { Zochowski } \text { et } \\
\text { al.,.(2001) }\end{array}$ & $90 \%$ & $94 \%$ & - & - & - & - & - & - \\
\hline $\begin{array}{l}\text { Levett } \text { et } \\
\text { al.,.2002 }\end{array}$ & $70 \%$ & - & - & - & $95.5 \%$ & $89.5 \%$ & - & - \\
\hline $\begin{array}{l}\text { Blacksell } \text { et } \\
\text { al.,.2006 }\end{array}$ & $60.9 \%$ & $65.6 \%$ & $20.0 \%$ & $92.2 \%$ & $65.2 \%$ & $45.4 \%$ & $14.4 \%$ & $90.2 \%$ \\
\hline $\begin{array}{l}\text { Panwala } \\
\text { Tanvi } \text { et al., } \\
\text { 2011 }\end{array}$ & 96.82 & 88.05 & 88.40 & 96.72 & 91.42 & 95.5 & 96.96 & 88 \\
\hline $\begin{array}{l}\text { Desakorn } \\
\text { varunee } \text { et } \\
\text { al.,2012 }\end{array}$ & 52.3 & 66.4 & - & - & 90.8 & 51.1 & - & - \\
\hline $\begin{array}{l}\text { Niloofa } \text { et } \\
\text { al.,2015 }\end{array}$ & 86.0 & 84.5 & 73.3 & 92.5 & 80.2 & 88.5 & 82.6 & 86.9 \\
\hline Our study & $89.7 \%$ & $100 \%$ & $100 \%$ & $89.3 \%$ & $90.3 \%$ & 100 & 100 & $88.46 \%$ \\
\hline
\end{tabular}

PanBio IgM ELISA recorded Sensitivity 90.3\%(28/31),Specificity $100 \%(23 / 23)$, PPV 100\%(28/28),NPV 88.46\%(23/26) and Kappa value was 0.888 with MAT(Table 4). Seropositivity for leptospiral antibodies was seen in 2,3 and 6 cases by Leptocheck,
PanBio ELISA and MAT respectively out of 50 asymptomatic cases.(Table 1).

Leptocheck-WB IgM and PanBio-ELISA $\mathrm{IgM}$, are genus specific serological tests for diagnosis of Leptospirosis.These tests 
reported IgM antibodies as early as 3-5 days of infection (Levett, 2001; WHO, 2003). Varying degree of sensitivity and specificity was shown by ICTs in previous studies (table2). Our study recorded a sensitivity of $75 \%$ and specificity of $95 \%$ with admission sample for Leptocheck WB in comparison with the reported data (Goris et al., 2013). But some of the earlier reports showed a higher sensitivity and lower specificity rate (Panwala et al., 2011; Panwala Tanvi et al., 2015 and Niloofa et al., 2015).This would be due to geographical distribution of leptospira serovars and time of blood collection.

Many published data cited PanBio ELISA to be highly sensitivity in early stages of infection which was in agreement with our study (Panwala et al., 2011; Niloofa, 2015 and Zochowski et al., 2001). Certain studies reported a lower rate of sensitivity and specificity (Blacksell et al., 2006 and Desakorn et al., 2012). In our study the ELISA test picked up more number of cases when tested with second sample (median -11 days)which was in accordance with other studies(table 3). In our study, Pan Bio Elisa was more sensitive in picking up leptospiral cases when compared to ICTs as reported by other studies (Panwala et al., 2011; Panwala Tanvi et al., 2015, Niloofa et al., 2015 and Zochowski et al., 2001).

Both the commercial kits showed relatively similar specificities with MAT where ELISA test recorded $100 \%$, in contrast to other studies (table 2 and 3).Both the tests showed great agreement with MAT (a kappa value of agreement of 0.707 and 0.888 for ICT and ELISA test respectively.

Microscopic agglutination test is the gold standard in the diagnosis of leptospirosis, but it requires maintainence of live strains of Leptospira for use as antigens. The test procedure is very laborious and also leads to cross infections among lab personnels. Therefore it is maintained only in reference laboratories. The sensitivity of MAT was found to increase with repeat serum samples collected during the course of infections for which paired sera is mandatory. Due to these limitations of MAT, rapid tests like ICTs and ELISA tests should be used as screening tests in tertiary hospital labs that do not have facilities for maintaining live strains.

In conclusion, in our study ICT and ELISA test were equally senstive when compared with MAT. Our study also recorded high specificity of ELISA test with MAT. Though MAT is a standard test is not feasible for small laboratories because of its limitations. Therefore combining the results of two rapid tests could increase the detection of suspected cases of acute leptospirosis with history of 4-6 days of febrile illness and thus preventing complications in future.

\section{References}

Adler, B., Murphy, A.M., Locarnini, S.A., Faine, S. 1980. Detection of specific antileptospiral immunoglobulins $\mathrm{M}$ and $\mathrm{G}$ in human serum by solid-phase enzymelinked immunoabsorbent assay. J. Clin. Microbiol., 11: 452-457.

Blacksell, S.D., Smythe, L., Rattanaphone, P., Michael Dohnt, Rudy Hartskeerl, Meegan Symonds, et al. 2006. Limited Diagnostic Capacities of Two Commercial Assays for the detection of Leptospira Immunoglobulin M Antibodies in Laos. Clin. vaccine immunol., p. 1166-1169.

Cole, J.R,. Sulzer, C.R. Jr, Pursell, A.R. 1973. Improved microtechnique for the leptospiral microscopic agglutination test. Appl. Microbiol., 25: 976-980.

Cumberland, P., C.O.R. Everard, and P.N. Levett. 1999. Assessment of the efficacy of an Igm-ELISA and Microscopic agglutination test (MAT) in the diagnosis of acute leptospirosis. Am. J. Trop. Med. Hyg., 61(5): pp. 731-734. 
Desakorn, V., Wuthiekanun, V., Thanachartwet, V., Sahassananda, D., Chierakul, W., Apiwattanaporn, A., et al. Accuracy of a commercial IgM ELISA for the diagnosis of human leptospirosis in Thailand. The American J. Trop. Med. Hygiene, 86(3): 524-7. doi: 10.4269/ajtmh.2012.11- 0423 PMID: 22403329; PubMedCentralPMCID:PMC3284374.

Faine, S. 1982. Guidelines for the Control of Leptospirosis. Geneva: World Health Organization.

Goris, M.G.A., Leeflang, M.M.G., Loden, M., Wagenaar, J.F.P., Klatser, P.R., et al. 2013. Prospective Evaluation of Three Rapid Diagnostic Tests for Diagnosis of Human Leptospirosis. PLoS Negl. Trop. Dis., 7(7): e2290. doi:10.1371/ journal.pntd.0002290.

Gussenhoven, G.C., Van der Hoorn, M.A., Goris, M.G., Terpstra, W.J., Hartskeerl, R.A., Mol, B.W. et al. 1997. LEPTO dipstick, a dipstick assay for detection of Leptospira specific immunoglobulin $\mathrm{M}$ antibodies in human sera. J. Clin. Microbiol., 35: 9297.

Levett, P.N. 2001. Leptospirosis. Clin. Microbiol. Rev., 14: 296-326

Levett Paul, N. and Songee. 2002. Branch. Evaluation of two enzyme-linked immunosorbent assay methods for detection of immunoglobulin $\mathrm{M}$ antibodies in acute leptospirosis. Am. J. Trop. Med. Hyg., 66(6): pp. 745-748.

Niloofa, R., Fernando, N., de Silva, N.L., Karunanayake, L., Wickramasinghe, H., Dikmadugoda, N., et al. 2015. Diagnosis of Leptospirosis: Comparison between Microscopic Agglutination Test, IgMELISA and IgM Rapid
Immunochromatography Test. PLOS ONE, 10(6): e0129236. doi:10.1371/ journal.pone.0129236.

Panwala, T., Mulla, S., Patel, P. 2011. Seroprevalence of leptospirosis in South Gujarat region by evaluating the two rapid commercial diagnostic kits against the MAT test for detection of antibodies to Leptospira interrogans. Nat. J. Community Med., 2: 64-70.

Panwala Tanvi, Sangeeta Rajdev, Summaiya Mulla. 2015. To Evaluate the Different Rapid Screening Tests for Diagnosis of Leptospirosis evaluate. J. Clin. Diag. Res., Vol-9(2): p21-24.

Smits, H.L., Eapen, C.K., Sheela Sugathan, S. et al. 2001. Lateral-flow assay for rapid serodiagnosis of human leptospirosis. Clin. Diagn. Lab. Immunol., 8, 166-169.

Terpstra, W.J., Ligthart, G.S., Schoone, G.J. 1980. Serodiagnosis of human leptospirosis by enzyme-linked-immunoabsorbent-assay (ELISA). Zentralbl Bakteriol Microbiol Hyg [A], 247: 400-405.

Winslow, W.E., Merry, D.J., Pirc, M.L., Devine, P.L. 1997. Evaluation of a commercial enzyme-linked immunosorbent assay for detection of immunoglobulin $\mathrm{M}$ antibody in diagnosis of human leptospiral infection. J. Clin. Microbiol., 35: 19381942.

World Health Organization. 2003. Human leptospirosis: guidance for diagnosis, surveillance, and control. World Health Organization, Geneva, Switzerland.

Zochowski, W.J., M.F. Palmer, T.J. Coleman. 2001. An evaluation of three commercial kits for use as screening methods for the detection of leptospiral antibodies in the UK. J. Clin. Pathol., 54: 25-30.

\section{How to cite this article:}

Ganesh, H.R., Vimal Kumar Karnaker, Veena A. Shetty. 2017. A Leptospirosis Workup by Evaluation of Efficiency of Two Rapid Immunodiagnostic Tests in Comparison with Microscopic Agglutination Test. Int.J.Curr.Microbiol.App.Sci. 6(1): 563-568. doi: http://dx.doi.org/10.20546/ijcmas.2017.601.069 